\title{
HEALTH TOURISM AS SCENE OF FORMATION OF HEALTH BEHAVIOUR - DEMONSTRATION OF POSSIBLE RESEARCH DIRECTIONS
}

\section{EGÉSZSÉGTURIZMUS, MINT EGÉSZSÉGMAGATARTÁS-FORMÁLÓ SZÍNTÉR - JÖVỐBENI KUTATÁSI IRÁNYOK BEMUTATÁSA}

\author{
Orsolya Savella ${ }^{1-}$ Márta Kóródi
}

Tourism and Catering Department, Business Administration Faculty, John von Neumann University, Hungary

\author{
Keywords: \\ health tourism \\ health behaviour \\ scene of health education \\ research directions \\ Kulcsszavak: \\ egészségturizmus \\ egészségmagatartás \\ egészségnevelési színtér \\ kutatási irányok
}

\begin{abstract}
Over recreation health tourism - mainly wellness tourism - services also ensure knowledge acquisition by informal learning for health. Depend upon former results this study formulates such examination directions by that this sector of tourism can became effective place of health education.

\section{Összefoglalás}

Az egészségturizmus - ezen belül fóként a wellness turizmus - sajátos eszközei által nemcsak a pihenés, kikapcsolódás élményével, hanem az informális tanulás útján történő, egészségre irányuló ismeretszerzés lehetôségével is rendelkezik. Jelen tanulmány egy alapkutatás eredményeire támaszkodva fogalmaz meg további kutatási irányokat, melyek alapot biztosithatnak arra, hogy a turizmus szóban forgó ágazata hatékony egészségnevelési színtérré váljon.
\end{abstract}

\section{Introduction}

The impact of assessment, which is the main purpose of the study, is not new for tourism researchers. Although the research areas do not reach the Michalkó's "lyrical model" (2007) in that at least 20 disciplines are needed for successful theoretical exploration, tourism has begun to examine as a system since 1980s. Among the descriptors of general models Krippendorf (1980), Mathieson and Wall (1982), Mill and Morrison (1985), Jafari (1987, 2000) and Lengyel (1986, 1993) can be mentioned.

\footnotetext{
${ }^{1}$ Contact Author. Tel.: +36 $56510300 / 5538$

E-mail address: savella.orsolya@uni.gk-neumann.hu
} 
Impact of assessments are the most commonly approached from the side of economics, but the work of Cohen (1984), Pizman and Millman (1984), Smith (1987) and Pearce (1981, 1993) is worth considering in the field of social sciences [15]. Narrowing the directions of impact assessments in this area, economic and social (Rátz, 1999, 2004) [13], [14], geographical (David, Szücs and Tóth, 2008; David and Szücs, 2009; Dávid et al, 2011) [2], [3] [4], sanitary (Dézsy, 2001, Borbás és Kincses, 1996, 2008) [5], [1], sociological (Kopp and Piko, 2004), [8], and the quality of life (Pál and Uzzoli, 1996, 2008; Utasi, 2007; Michalkó, 2010) [12], [20], [9] approaches can be found. According to the results of a mainly pedagogical questionnaire survey on health tourism attendees $(\mathrm{N}=704)$, health tourism provides an opportunity for informal growth, which has a short and long-lasting effect on the health behaviour of visitors [15]. This paper presents this area from educational aspect and according to the most important conclusions further suggestions are composed for deeper recognition of the area by that it can be possible to develop procedures tailored to the main goals of health education.

\section{Literature review}

The starting point of the research was the identification of the knowledge gained by informal way by health tourism travel, and its impact on health behaviour. The main aim was to promote and improve the health of the population by wellness tourism, and wellness tourism appeared as scene of informal learning.

The study was carried out by exploring the theoretical contexts of three disciplines. An international report issued by UNESCO (2016) Lifelong Learning Institute [19] was a point of contact in this topic, where learning as a key factor in the development of disease prevention and health-conscious behaviour that helps to develop the positive improvement of health behaviour as mentioned a "learnable" skill by Feketéné (2017) 6], which also implies the appreciation of the role of informal learning presented in the next chapter.

Further point of attachment was given to the rational model of health education (WHO, 2012) [22] and the research attainable in foreign tourism literature (Weiler and Ham, 2001; Tisdell and Willson, 2005; Orams, 1997; Hughes et al. 21], [18], [11], [7]. According to the rational model, changes in knowledge and attitudes play a central role in the changes on health of individuals. In case of the rational model over knowledge and attitude, forming of behavioural intention is appearing as additional important factor of health behaviour varying. Exploration of the area was difficult by the fact that tourism researches have always investigated the impact of procedures applied deliberately such as interpretative methods.

The site also appeared as an interface. According to different definitions, distribution and characteristics of health tourism, it is essentially an area of tourism where the goal is the prevention, the rehabilitation, the preservation and the development of health. Thus, taking into account these characteristics, this research was basically limited to system of wellness tourism by Molnár (2011), assuming that the accumulated experience and acquired knowledge of the utilized and tested services have a potential, health-promoting effect of changing on attitude, on intention, and on behavioural changes [10]. And since health tourism still does not employ pedagogical health care procedures, the primary focus was on the presence of knowledge gained by informal learning. For the purpose of further coherences of theories, on the basis of former theoretical backgrounds and research aspects a new informal learning concept has been formulated. According to this, informal learning is a conscious or nonconscious learning process (gaining experience) during leisure time activities that in given environment entails the acquisition of new knowledge, the updating, expansion, change of existing knowledge and the development of attitudes in connection with health have short and long-term effect for the individual's daily life and behaviour "[15].

\section{Methodology}

The research sought to find out how wellness tourism could become a health education scene in which we use informal learning as a tool? 
Based on the exploration of the theoretical knowledge and interfaces of the three disciplines, a questionnaire was developed, and according to the results of preliminary tests, including factor analysis and calculation of Cronbach alpha [16], was suitable for the realization of the research objectives. The questionnaire contains the learning modes according to the new informal learning concept, but knowledge acquaintance was used in one variable that was created later in the database. Effect of learning on attitudes with health and behavioural intentions has been established by non-parametric (Kruskal-Wallis) and other descriptive statistical (median and mode) calculations. By the same way, further correlations have been explored such as how the behavioural intention formed during travel influenced the health behaviour of the person following his or her journey [15].

\section{Results}

The presence of informal learning, especially during wellness tourism trips, has been proven true [17]. Learning areas were grouped by the available wellness services. Thus the questionnaire contained areas such as physical health; mental health; stress management; spirituality, holistic; body and beauty care; nutrition or a new sport, leisure activity.

Influence of learning on the attitudes changed during health tourism travel that has caused generally poor, but in two cases (mental health and stress management) statistically significant changes in health-related opinion. Changes in behavioural intentions were found in all seven learning categories. According to the study high level of knowledge gained during travel that was shown in mental health, in the lowest level stress management and nutrition categories changed. The most commonly reported changes in behavioural intention were appeared in area of appropriate rate of work and rest, conscious nutrition and search for targeted information in theme of health. Based on the results of the research, it can be stated that travel is inherently capable of developing the intention of changing health-protection behaviour (screening tests) but without additional motivation for maintenance of behaviour, short-term effect was appeared. The established behavioural intention in some cases (also during regular screening tests and low intensity physical activity) can be sustained have the long term effect, even generating habitual behaviour patterns. In addition, in my opinion, it can be concluded that both the temporary and the long-term effects are related to such activities that can be easily implemented by individuals, for example they do not require any particular lifestyle change and persistence on the part of the individual, otherwise that factors would be done these activities more difficult [15].

\section{Further research directions and additional suggestions for modifying of the questionnaire}

In the case of the effect of knowledge on the attitude to health, 3 suggestions have been made. In case of rational model [22] in health education explains changes in attitudes after the acquisition of knowledge. This factor is also reflected in the model used in international tourism literature [21], [11], [7]. In the study the acquisition of knowledge has not changed comprehensively the change in health opinion, but it can be stated that the behavioural intention has occurred. Another assumption about the results obtained is that visitors may have given health-consciousness on which the journey did not necessarily change the cause of further health-related behaviours. The acquired knowledge has highlighted the change of opinion, but it has not been possible to show the connection between opinion and behavioural intention. It would also be useful to know what specific services and what the enrichment of the knowledge led to the observed attitudinal change, and whether this influenced attitude influence of changing intention.

Acquiring knowledge has a global impact on health-related behaviour. In this area two further proposals have been formulated for comparability and clarification of results. One of these the condition for changing behaviour is predominantly the intensity level of behavioural intention. We do not have information about this. Another thing that international research results supported that the intentions of the effects are appeared of interpretative tools, but in our case, these results have occurred without any interpretative tool. If we accept the 
advertising material, brochures and staff used in health tourism as an interpretive way, it would also be worthwhile examining the difference in the behavioural intent of those who gained information from those and who did not use this kind of tools through their journey. This question also would highlight visitors' sources of knowledge, by that consumers' intention would have been influenced by pedagogically based methods.

Research has shown that the intention has a short-term effect on visitors' health behaviour after travelling. The need for change requires the formulation of two questions. What factors influenced the temporary maintenance of the activity? What was the lack of conditions that caused the termination of the activity?

In case of identified long-term health activities, one question has been formulated to gain more precise information. What influencing factors play a part in keeping this behaviour after travelling?

\section{Conclusions}

The results of basic research have identified the presence of informal learning and its impact on health behaviour, but have also highlighted the need for further steps.

In case of above-mentioned questions of the questionnaire, the changes / additions are aimed at:

- Attitudinal measurement before and after the health tourism trip, reinventing attitudinal statements and exploring information sources that affect the opinion,

- Exploring sources of information that is causing change in behaviour,

- The facilitating or preventing factors of temporary behaviour following the journey,

- Motivation factors of long-term behaviour after travelling.

The necessity of further refinement of the measure instrument not only implies providing deeper information and correlations in the visitor's health-related attitude, behaviour intention, and health behaviour but to provide a theoretical basis for a subsequent healthcarebased, pedagogically well-established, effective health behaviour change processes.

\section{Acknowledgement}

This research is supported by EFOP-3.6.1-16-2016-00006 "The development and enhancement of the research potential at John von Neumann University" project. The Project is supported by the Hungarian Government and co-financed by the European Social Fund.

\section{Bibliographical References}

[1] Borbás, I. - Kincses, Gy. (2007): Egészségügyi ellátó rendszerek az Európai Unió Tagállamaiban. Egészségügyi Stratégiai Kutatóintézet, Egészségügyi Rendszertudományi Iroda, Budapest, pp. 8-16.

[2] Dávid, L. - Bujdosó, Z. - Tóth, G. (2008): Tourism planning in the Hajdú-Bihar - Bihor Euroregion. In: SüliZakar, I. (Ed.) Neighbours and partners on the two sides of the border. Proceeding Book, Debrecen, pp. 323332.

[3] Dávid, L. - Szűcs, Cs. (2009): Building of networking, clusters and regions for tourism in the Carpathian Basin via information and communication technologies. In: Netcom - Networks and Communications Studies 23 (12) pp. 63-74.

[4] Dávid, L. - Tóth, G. -Bujdosó, Z. - Remenyik, B. (2011): The role of tourism in the development of border regions in Hungary, In: Romanian Journal of Economics 32 (2) pp. 109-124.

[5] Dézsy, J. (2001): Mi az egészségünk értéke? In: Egészségügyi Gazdasági Szemle 39 (4) pp. 316-323.

[6] Feketéné Szakos, É. (2017): A felnőttkori tanulás és képzés hatásai az egészségre - kutatási eredmények és a GRALE 3 jelentés tükrében, In: Fodorné Dr. Tóth, K.: Felsőoktatás, életen át tartó tanulás és az ENSZ fenntartható fejlesztési célok megvalósítása. „MELLearN - Felsőoktatási Hálózat az Életen át tartó tanulásért” Egyesület, Pécs, pp. 227-234.

[7] Hughes, K. - Packer, J. - Ballantyne, R. (2011): Using post-visit action resources to support family conservation learning following a wildlife tourism experience. In: Environmental Education Learning, 17 (3) pp. 307-328.

[8] Kopp, M. - Pikó, B. (2004): A kultúra és életminőség kapcsolata. In: Bácsy, E. - Mikola, I. (Ed.) Civilizáció és egészség. MTA Stratégiai Kutatások, Budapest, pp.139-158.

[9] Michalkó Gábor (2010): Boldogító utazás: a turizmus és az életminőség kapcsolatának magyarországi vonatkozásai. MTA Földrajztudományi Kutatóintézet, Budapest 
[10] Molnár Csilla (2011): Az egészségturiszikai fejlesztések hatásai, különös tekintettel Kelet-Magyarországra, Doktori (PhD) Értekezés, Széchenyi István Egyetem, Regionális és Gazdaságtudományi Doktori Iskola, Győr

[11] Orams, M. B. (1997): The effectiveness of environmental education: Can we turn tourists in 'Greenies'? Progress in Tourism and Hospitality Research, 3. pp. 295-306.

[12] Pál, V. - Uzzoli, A. (2008): Az emberiség egészsége - a 21. század kihívásai. Földrajzi Közlemények, 132 (4) pp. 471-488.

[13] Rátz, T. (1999): A turizmus társadalmi-kulturális hatásai. Doktori (PhD) értekezés, Budapesti Corvinus Egyetem, Gazdálkodástani Doktori Iskola, pp. 19-25.

[14] Rátz, T. (2004): Zennis és Lomi Lomi avagy új trendek az egészségturizmusban. In: Aubert, A. - Csapó, J. (Ed.): Egészségturizmus. Főiskolai jegyzet, Pécs, PTE TTK Földrajzi Intézet, pp. 46-65.

[15] Savella, O. (2017): Informális tanulás egészségmagatartás-formáló hatása az egészségturizmusban, Doktori Értekezés, Eszterházy Károly Egyetem, Neveléstudományi Doktori Iskola, Eger

[16] Savella, O. - Horváth, H. A. - Dudás, P. - Fritz, P.(2017):"Informális tanulás az egészségturizmusban" mérésére alkalmas kérdőív tesztelése faktoranalízis és Cronbach-teszt alkalmazásával. In: Magyar Sporttudományi Szemle 18:(69) pp. 30-36.

[17] Savella, O. - Horváth, H. A. - Csizmásné Tóth, J. - Dudás Péter (2017): Az egészségturisztikai utazások során szerzett ismeretek hatása az egészséggel kapcsolatos viselkedési szándék kialakulására. In: Gradus, 4 (2) pp. 91-97.

[18] Tisdell, C. - Wilson, C. (2005): Perceived impacts of ecotourism on environmental learning and conservation. Turtle watching as a case study. In: Environment, Development and Sustainability, 7. pp. 291-302.

[19] UNESCO Institute for Lifelong Learning, Annual Report 2016. Available: http://unesdoc.unesco.org/images/0025/002506/250689e.pdf [Accessed: 20-11-2017]

[20] Utasi, Á. (Ed.) (2007): Az életminőség feltételei. MTA Politikai Tudományok Intézete, Múhelytanulmányok Digitális Archívum (1). Budapest.

[21] Weiler, B. - Davis D. (1993): An exploratory investigation into the roles of the nature-based tour leader. Tourism Management. 14 (2) pp. 91-98.

[22] World Health Organization (2012): Health education. Theoretical concepts, effective strategies and core competencies. A foundation document to guide capacity development of health educators. Regional Office for the Eastern Mediterranean, Cairo 
